Asian J. Med. Biol. Res. 2016, 2 (3), 409-413; doi: 10.3329/ajmbr.v2i3.30111

\author{
Asian Journal of \\ Medical and Biological Research \\ ISSN 2411-4472 (Print) 2412-5571 (Online) \\ www.ebupress.com/journal/ajmbr
}

\title{
Article \\ Effects of periparturient anthelmintic treatment on milk yield and quality in dairy cows
}

Adil Borman ${ }^{1 *}$, Md. Faruk Islam ${ }^{1}$, Md. Shajedur Rahman ${ }^{1}$, Md. Fazlul Hoque ${ }^{1}$, Sandip Kispotta ${ }^{1}$ and Md. Anowarul Haque ${ }^{2}$

${ }^{1}$ Department of Medicine, Surgery and Obstetrics, Hajee Mohammad Danesh Science and Technology University, Dinajpur, Bangladesh

${ }^{2}$ Department of Surgery and Obstetrics, Bangladesh Agricultural University, Mymensingh, Bangladesh

*Corresponding author: Adil Borman, MS in Medicine, Department of Medicine, Surgery and Obstetrics, Hajee Mohammad Danesh Science and Technology University, Dinajpur, Bangladesh. Phone: +8801737573542; Email: aborman.adi@gmail.com

Received: 15 July 2016/Accepted: 03 August 2016/ Published: 29 September 2016

\begin{abstract}
This study was conducted to determine the efficacy of anthelmintics against gastrointestinal parasite in periparturient dairy cows and its effect on milk yield and quality. Sixty mixed breed pregnant cows were selected divided into four groups, A $(n=18), B(n=14), C(n=16)$ and $D(n=12)$ and group D kept as control. Cows of group A were treated with Nitroxynilat the rate of $10 \mathrm{mg} / \mathrm{kg}$ bwt. s/c, 30 days before parturition and average feacal egg per gram(EPG) was reduced from $506.1 \pm 172.3$ to $157.8 \pm 24.9$ within 14 days. Group B were treated with combined triclabendazole and levamisoleat the rate of $19.5 \mathrm{mg} / \mathrm{kg}$ bwt. orally at calving. The average EPG was reduced from $967.7 \pm 237.1$ to $172.0 \pm 25.9$. Group C were treated with same as group B at calving and 42 days after. The mean EPG fall from $794.6 \pm 310.5$ to $166.7 \pm 26.2$.In group D average EPG increased from $791.7 \pm 268.5$ to $864.2 \pm 290.7$. The mean change in EPG 14 days after treatment was significantly higher $(\mathrm{p}<0.05)$ in treated $(79.1 \%)$ cows than control $(-9.2 \%)$. The average milk yield in all treated cows was significantly $(\mathrm{p}<0.01)$ higher in treated lactation $(2.5 \pm 0.7)$ than previous lactation $(2.2 \pm 0.7)$ and control cows $(2.2 \pm 0.8)$. Although, milk yields were higher in second parity $(2.5 \pm 0.7)$ than the first $(2.4 \pm 0.7)$, there was no significant difference $(\mathrm{p}>0.05)$. The percentage of milk fat, protein, lactose, SNF was significantly higher $(\mathrm{P}<0.05)$ in treated group than the control group.
\end{abstract}

Keywords: anthelmintic; milk; SNF; protein; parturition

\section{Introduction}

Milk has long been recognized as an valuable food of pastoralist diets in all the world, also it is a nutrient food and is recognized to contribute a high proportion of the nutrients, such as micronutrients, include calcium, phosphorus, vitamins like $\mathrm{B}$ and $\mathrm{D}$, high quality protein such as casein protein, also fatty acid composition of milk fat has relation to its potential health benefit and impact on the human health (Frelich et al., 2012). Milk for human consumption can be obtained from a number of domesticated animals including sheep, goat, buffalo and cow, whose milk is by far the most consumed. Fresh cow milk contains approximately $3.5 \%$ protein, $80 \%$ casein, $15 \%$ whey protein, as well as vitamins, and lipids, all of which provide necessary ingredients for growth (Heck et al., 2008).Different factors, such as race of cows, genetic variants, stage of lactation and environmental factors which can significantly affect on milk component and properties of milk (Bernabucci et al., 2002). The focused of global warming may be felt in a high variety of economic, social, and environmental sectors, including marine life, energy usage, forestry, water resources and human health, rangeland ecosystems, etc. Today's, considerable research has show been directed at an assessment of the effect of climate on most of these sectors (Klinedinst et al., 1993). Along with other constrains, parasitic infestation interrupts production potential 
of dairy cows in Bangladesh (Jabbar and Green, 1983). Parasitism results in a reduced nutrient supply to the host through voluntary reductions in food intake and reduced food efficiency and it has major detrimental effects on the efficiency of production of ruminants through losses up of to $50 \%$ are not uncommon. Deworming strategy can reduce the occurrence parasitic infestation and economic loss to ensure the continued production of milk. There is no comprehensive precise data are available on the effects of parasitism on milk yield in dairy cows of Bangladesh. This study was conducted to improve the quantity and quality of milk production through anthelmintic treatment during periparturient period in cows. The periparturient period typically defined as the period immediately before and after calving is a challenging time for dairy cattle that must cope with physiological, metabolic and endocrine changes as well as a variety of environmental and managemental stressors. The objective is to the efficacy of periparturient anthelmintics treatment on milk yield and the effects of periparturient anthelmintics treatment on milk composition.

\section{Materials and Methods}

A total 60 multiparous mixed breed pregnant cows were selected from 70 household of different area of northern part of Bangladesh. The experimental cows were divided into four groups, A ( $n=18), B(n=14), C$ $(\mathrm{n}=16)$ and $\mathrm{D}(\mathrm{n}=12)$ and group $\mathrm{D}$ were kept as control. Cows of group A were treated with Nitroxynilat the rate of $10 \mathrm{mg} / \mathrm{kg}$ bwt. s/c, 30 days before parturition, Group B were treated with combined triclabendazole and levamisoleat the rate of $19.5 \mathrm{mg} / \mathrm{kg}$ bwt. orally at calving, Group C were treated with same as group B at calving and 42 days after and samples were collected (both feces and milk) from over a period of one year fromJuly 2014 to June 2015. The fecal samples were examined (MaMaster method) in the laboratory of Pathology and Parasitology under the department, faculty of Veterinary and Animal Sciences, Hajee Mohammad Danesh Science and Technology University, Dinajpur, Bangladesh. After collection of 4 grams of faeces the sample were placed into a container. After sample collection, $56 \mathrm{ml}$ of chosen flotation fluids was added. Stirred the content of the beaker thoroughly with a fork or spatula. After that we had filtered the faecal suspension through a tea strainer or double layer of cheesecloth or dental napkin into the second container. Then stirred the filtrate in container two with a Pasteur pipette. We used the pipette for withdraw a sub-sample as the filtrate is being stirred. Then we stired the fluid and fill first compartment of the McMaster counting chamber with the sub sample. After that we stired the fluid again and filled second chamber with another sub sample. After that we placed the slide under microscope and observed parasitic eggs under microscope.

The number of eggs per gram can be calculated by using some methods. Firstly counted number of eggs within the grid of each chamber, ignoring those outside the squares; and secondly multiplied the total eggs by 50 - this gives the eggs per gram of faeces (e.p.g).

Milk samples were collected from each cow once a month and analyzed for the percentage of milk fat, protein, lactose, solid not fat (SNF) and minerals. The milk compositions were analyzed by using the automated milk composition analyzer (MILKOTESTER ${ }^{\circledR}$, Milk analyzing device, Model: MINI 3, Milkotester Ltd. Bulgaria) in CARE Rangpur branch, RO circuit house road dhap Rangpur-5400.All data were analyzed for descriptive statistics (i.e. means, frequencies) using statistical package for social sciences (SPSS-17.0) computer program. The SPSS package was used for performing t-test, for comparing the variables.

\section{Results}

The efficacy of anthelmintic treatment at different stages of periparturient periods have been presented in Table 1. The cows of group A which were naturally infested with gastrointestinal nematode parasites treated with Nitroxynilat the rate of $10 \mathrm{mg} \mathrm{kg}^{-1}$ body weight subcutaneously 30 days before parturition was due. It showed the average EPG reduced from 506.1 \pm 172.3 to $157.8 \pm 24.9$ and the percentage of EPG reduction was 68.97 on $14^{\text {th }}$ day of post treatment i.e. efficacy of Nitroxynil was $68.97 \%$. The cows of group B were treated with combination of triclabendazole and levamisoleat the rate of $19.5 \mathrm{mg} \mathrm{kg}^{-1}$ body weight orally at single dose during calving, where the average EPG reduced from 794.6 \pm 310.5 to $166.7 \pm 26.2$ and the percentage of EPG reduction was 79.02 i.e. efficacy of triclabendazole and levamisole was $79.02 \%$. The cows of group $\mathrm{C}$ were treated with combination of triclabendazole and levamisoleat the rate of $19.5 \mathrm{mg} \mathrm{kg}^{-1}$ body weight orally at double doses during calving and 42 days after, showed the average EPG fell from967.7 \pm 237.1 to $172.0 \pm 25.9$ and the percentage of EPG reduction was 82.21 i.e. efficacy of triclabendazole and levamisole was $82.21 \%$. Whereas cows of group D (untreated control group), showed increased EPG from $791.7 \pm 268.5$ to $864.2 \pm$ 290.7 i.e. on $14^{\text {th }}$ day of post-treatment increased EPG was $9.22 \%$. The mean change in EPG 14 days after treatment was significantly higher $(\mathrm{p}<0.05)$ in treated $(79.1 \%)$ cows than control $(-9.2 \%)$. 
Table 1. Efficacy of anthelmintics against gastrointestinal parasites in dairy cows.

\begin{tabular}{|c|c|c|c|c|c|}
\hline Groups & Drugs with dose & $\begin{array}{l}\text { Pre-treatment } \\
\text { EPG }(\text { Mean } \pm \text { SD })\end{array}$ & $\begin{array}{l}\text { Post-treatment } \\
\text { EPG }(\text { Mean } \pm \text { SD) }\end{array}$ & $\begin{array}{l}\% \text { of EPG reduction } \\
\text { on } 14^{\text {th }} \text { day }\end{array}$ & P-value \\
\hline $\mathrm{A}(\mathrm{n}=18)$ & $\begin{array}{l}\text { Nitroxynil }\left(\text { Dovinix }{ }^{\circledR}\right) \\
\text { at the rate of } 1 \mathrm{ml} / 25 \mathrm{~kg}\end{array}$ & $506.11 \pm 172.25$ & $157.78 \pm 24.86$ & 68.97 & 0.01 \\
\hline$B(n=14)$ & $\begin{array}{l}\text { LevamisolandTriclabend } \\
\text { azol }\left(\text { Endex }^{\circledR}\right) \text { at the rate } \\
\text { of } 19.5 \mathrm{mg} / \mathrm{kg} \text { bwt. at } \\
\text { calving }\end{array}$ & $794.6 \pm 310.5$ & $166.7 \pm 26.2$ & 79.02 & 0.01 \\
\hline$C(n=16)$ & $\begin{array}{l}\text { LevamisolandTriclabend } \\
\text { azol }\left(\text { Endex }^{\circledR}\right) \text { at the rate } \\
\text { of } 19.5 \mathrm{mg} / \mathrm{kg} \text { bwt. At } \\
\text { calving }+42 \text { days after }\end{array}$ & $967.67 \pm 237.09$ & $172.00 \pm 25.91$ & 82.21 & 0.01 \\
\hline $\begin{array}{l}D \\
(n=12)\end{array}$ & Control (untreated) & $791.67 \pm 268.52$ & $864.17 \pm 290.71$ & -9.22 & .976 \\
\hline $\begin{array}{l}\text { Over all } \\
\text { Treated }\end{array}$ & Anthelmintics & $794.58 \pm 310.49$ & $166.67 \pm 26.20$ & 79.09 & 0.01 \\
\hline
\end{tabular}

The average daily milk yield of all groups was shown in Table 2 . The milk yield were in group A, B, C and D in lactations previous and treated lactation was $2.3 \pm 0.7,2.6 \pm 0.7 ; 2.5 \pm 0.8,2.7 \pm 0.9 ; 2.1 \pm 0.6,2.8 \pm 0.8$ and $2.2 \pm 0.9,2.2 \pm 0.8$ litres, respectively. Average milk yield of all treated groups was significantly higher $(\mathrm{p}<0.01)$ in treated lactation than the previous lactation.

Table 2. Average daily milk yield (lit./cow) of all cows.

\begin{tabular}{llll}
\hline \multirow{2}{*}{ Groups } & \multicolumn{1}{c}{ Milk yield (lit./cow) } & \multirow{2}{*}{ P-value } \\
\cline { 2 - 4 } & Previous lactation & Treated lactation & 0.01 \\
$\mathrm{~A}(\mathrm{n}=18)$ & $2.3 \pm 0.7$ & $2.6 \pm 0.7$ & 0.01 \\
$\mathrm{~B}(\mathrm{n}=14)$ & $2.5 \pm 0.8$ & $2.7 \pm 0.9$ & 0.01 \\
$\mathrm{C}(\mathrm{n}=16)$ & $2.1 \pm 0.6$ & $2.8 \pm 0.8$ & NS \\
$\mathrm{D}(\mathrm{n}=12)$ & $2.2 \pm 0.9$ & $2.2 \pm 0.8$ & \\
\hline
\end{tabular}

$\mathrm{NS}=$ Not significant

Table 3 shows the average milk yield in treated cows was significantly $(\mathrm{p}<0.01)$ higher in treated lactation $(2.5 \pm 0.7)$ than the previous lactation $(2.2 \pm 0.7)$ and similarly average milk yield was significantly $(\mathrm{p}<0.01)$ higher in treated group $(2.5 \pm$ $0.7)$ than the control group $(2.2 \pm 0.8)$.

Table 3. The milk yield difference between two lactations.

\begin{tabular}{|c|c|c|c|}
\hline \multirow{2}{*}{ Groups } & \multicolumn{2}{|c|}{ Milk yield (lit./cow) } & \multirow{2}{*}{ P-value } \\
\hline & Previous lactation & Treated lactation & \\
\hline Treated $(n=48)$ & $2.2 \pm 0.7$ & $2.5 \pm 0.7$ & .01 \\
\hline Control $(\mathrm{n}=12)$ & $2.2 \pm 0.9$ & $2.2 \pm 0.8$ & NS \\
\hline
\end{tabular}

Although, milk yields were higher in second parity $(2.5 \pm 0.7)$ than the first $(2.4 \pm 0.7)$, there was no significant $(\mathrm{p}>0.05)$ difference (Table 4).

Table 4.The milk yield of cow in different parities.

\begin{tabular}{|c|c|c|c|}
\hline \multirow{2}{*}{ Parity } & \multicolumn{2}{|c|}{ Milk yield (lit./cow) } & \multirow{2}{*}{ P-value } \\
\hline & Previous lactation & Treated lactation & \\
\hline $\begin{array}{l}1 \\
2\end{array}$ & $\begin{array}{l}2.2 \pm 0.7 \\
2.4 \pm 0.7\end{array}$ & $\begin{array}{l}2.4 \pm 0.7 \\
2.5 \pm 0.7\end{array}$ & NS \\
\hline
\end{tabular}

$\mathrm{NS}=$ Not significant

The average value of solid composition of milk was shown in Table 5. The percentage of milk fat, protein, lactose, Solid Not Fat (SNF) and minerals in treated and control groups was 4.4, 4.0; 3.8, 3.5; 5.5, 5.3; 10.1, 10.1 and $0.6,0.6$, respectively. The milk protein percentage was significantly higher $(\mathrm{p}<0.05)$ in treated group than the control group. There was no significant difference $(p>0.05)$ in percentage of other milk components. 
Periparturient anthelmintic treatment reduced the gastrointestinal parasitic load and improved milk yield and protein percentage.

Table 5. Total solid compositions of milk samples.

\begin{tabular}{llllll}
\hline \multirow{2}{*}{ Groups } & \multicolumn{5}{c}{ Milk composition (average values in percentage) } \\
\cline { 2 - 6 } & Fat & Protein & Lactose & SNF & Minerals \\
\hline Treated & 4.356 & 3.758 & 5.48 & 10.092 & 0.628 \\
$\begin{array}{l}\text { Control } \\
\text { (Untreated) }\end{array}$ & 4.018 & 3.458 & 5.324 & 10.054 & 0.594 \\
\hline
\end{tabular}

\section{Discussion}

The efficacy of anthelmintic treatment at different stages of periparturient periods in groups $\mathrm{A}, \mathrm{B}$ and $\mathrm{C}$ were $68.97 \%, 79.02 \%$ and $82.21 \%$, respectively. The efficacy of treatment was corresponded to the findings of earlier studies (Singh et al., 1993; Gupta et al., 1989; Mahbub, 1996). Those studies reported 89.5\%-100\% efficacy against endoparasitic infection in cattle or other small ruminants reared in tradition system in Bangladesh. The present findings were coincided with the earlier researcher Ratnaparki et al. (1992) who report the efficacy of triclabendazole alone $80 \%$ in cattle. The very effective performance of triclabendazole along with levamisole against endoparasites in the current study also coincided with the performance of triclabendazole alone reported earlier in cattle (Mahbub, 1996). Moreover, using the levamisole (with triclabendazole) in this study could have trend of body weight gain (Hassan, 2012) modulated the body's immune system to give necessary protection against different infectious organisms (Mahbub, 1996). However, in this study has not studied immune status and body weight gain with the administration of levamisole along with triclabendazole. Some other anthelmintics have showed the most effective performance against gastrointestinal parasites. Williams (1991) compared the anthelmintic efficacy of levamisole, albendazole and fenbendazole and $100 \%$ effective against Haemonchus adults and L4, 85.6\% against T. axei, and $94.6 \%$ and $89.59 \%$ effective against Cooperia spp. adults and L4, respectively. Whereas Cornwell et al. (1973) found that infections with Ostertagialess than 21 days old were not affected by morantel tartrate, and even at a $2 \mathrm{X}$ dose the effect was minimal (52\%). On the other hand, White and Standen (1953); recommended that piperazine has the efficacy more than 70\% from the other anthelmintic. Aktaruzzaman et al. (2012) evaluated the efficacy of ivermectin, fenbendazole and albendazole against gastrointestinal nematodes in naturally infected ruminants they showed the efficacy of ivermectin was $100 \%$, followed by fenbendazole $95.33 \%$ and albendazole $90.11 \%$. The average milk yield of cows was significantly $(\mathrm{p}<0.01)$ higher in treated lactation $(2.5 \pm 0.7)$ than the previous lactation $(2.2 \pm 0.7)$ and similarly the average milk yield was significantly $(\mathrm{p}<0.01)$ higher in treated group $(2.5 \pm 0.7)$ than the control group $(2.2 \pm 0.8)$. The findings of the study have been supported by the other researchers (Haq et al., 1992; Gross et al., 1999) who found that deworming helps to increased milk production 0.5 litres per cow per day. Sanyal et al. (1992) reported that anthelmintics treated cows produces 142 litres more milk over 100 days, with extension of lactation length and reducing the length of time of onset of oestrus. Ploeger et al. (1990) determined milk production per cow per lactation from 81 farms he observed in treated cows produced $132.9 \mathrm{~kg}$ milk per cow per lactation more than untreated cows (P less than 0.01).The mean herd milk yield response to treatment varied from -889 to $+1231 \mathrm{~kg}$ milk per cow per lactation. Gross et al. (1999) investigated in 70 of 87 experiments and there was an increase in $80 \%$ milk production after anthelmintic treatment. In this study milk protein percentage was significantly higher $(\mathrm{p}<0.05)$ in treated cows without other milk components. The finding was coincided with findings of Farque et al. (2007) who reported that anthemintic treatment with concentrate feed supplementation significantly increased milk protein and ash percentage. This results also has been supported by the Gross et al. (1999) and Reist et al. (2002) who reported that milk production increased $(0.6 \mathrm{~kg} / \mathrm{day})$ with the yield of milk fat and protein percentage after anthelmintics treatment.

\section{Conclusions}

The periparturient anthelmintics treatment has shown very satisfactory performances in terms of the reducing of gastrointestinal parasitic load and the changing of milk components. Periparturient deworming may be used as the most efficient strategy to improve milk production and quality in cows.

\section{Acknowledgements}

This work was supported by Department of Medicine, Surgery and obstetrics, Hajee Mohammad Danesh Science and Technology University, Dinajpur, Bangladesh. 
Conflict of interest

None to declare.

\section{References}

Aktaruzzaman M, MSD Islam, MN Uddin, SA Belal and S Sarkar, 2012.Comparative efficacy of Ivermectin (Inj. Vermic), Fenbendazole (Peraclear) and Albendazole (Almex-Vet) against gastrointestinal nematodiasis in ruminants. Journal of Research in Pharmacology, 1: 1-8.

Bernabucci, N, Lacetera, B Ronchi and A Nardone, 2002. Animal Research, 51: 25-33.

Cornwell Jones RM and JM Pott, 1973. Br. Vet. J., 129: 518-525.

Frelich J, M Lakota, O Hanoi, J Pickax, E Samovar, A Węglarz and P Zapletal, 2012. Animal Science Papers and Reports,30: 219-229.

Gross SJ, WG Ryan and HW Ploeger, 1999.Anthelminthic treatment of dairy cows and its effect on milk production.Vet. Rec., 144: 581-587.

Gupta SC, R Chandra and SC Yadav, 1989. Efficacy of triclabendazole against experimental Fasciolagigantica infection in sheep, goat, buff alo and rabbit. Indian Veterinary Journal, 66: 680-682.

Haq S, MJFA Taimur, MF Mian and SMZH Chowdhury, 1992. Gastrointestinal helminths of cattle in Bangladesh. Proceedings of the First Annual Conference of the Bangladesh Society for Parasitology, pp. 7882.

Hassan MM, MH Ahasanul, SKM Azizul Islam, SA Khan, M Belayet, M Hossain and Q Banu, 2012. Efficacy of anthelmintics against parasitic infections and their treatment effect on the production and blood indices in Black Bengal goats in Bangladesh.Turkey. Jour. Vet. Anim. Sci., 36: 400-408.

Heck JML, C Olieman, A Schennink, HJF van Valenberg, MHPW Visker, RCR Meuldijk and ACM van Hooijdonk, 2008. International Dairy Journal, pp.18-548.

Jabbar M and DAG Green, 1983.The status and potential of livestock within the context of agricultural development policy in Bangladesh.The University of Wales, Aberystwyth, United Kingdom.

Klinedinst P, D Wilhite, GL Hahn and K Hubbard, 1993. The potential effects of climate change on summer season dairy cattle milk production and reproduction. Climatic Change, 23: 21-36.

Mahbub A, 1996. Anthelmintic efficacy against fasciliasis and gastrointestinal nematodiasis with haematobiochemical changes in sheep and goats. MSc Thesis. Bangladesh Agricultural University, Mymensingh, Bangladesh.

Ploeger HW, A Kloosterman, G Bargeman, L von Wuijckhuise and R van den Brink,1990. Milk yield increase after anthelmintic treatment of dairy cattle related to some parameters estimating helminth infection. Vet. Parasitol., 35:103-16.

Ratnaparhki MR, UV Shastri, BW Narlandkar, SU Digraskar and NM Degloorkar, 1992. A note on efficacy of some flukicides against Fasciola infection in domestic animals. Indian Journal of Veterinary Medicine, 12: 20.

Reist M, TDE Medjitna, U Braun and K Pfister, 2002. Effect of a treatment with eprinomectin or trichlorfon on the yield and quality of milk produced by multiparous dairy cows. Veterinary Record, 151: 377-380.

Sanyal PK, DK Singh and MR Knox, 1992.The effect of peri-parturient anthelmintic treatment on the productivity of dairy cattle in subtropical western India. Veterinary Research Communication, 16: 445-451.

Singh H, JS Gill and HS Bali, 1993. Comparative field trials of five anthelmintics in sheep naturally infected with gastrointestinal nematodes. Indian Journal of Parasitology, 17: 71-73.

White R and O Standen, 1953. Piperazine in the treatment of threadworms in children; report on a clinical trial. British Med. J., 2: 755-761.

Williams JC, 1991. Efficacy of albendazole, levamisole and fenbendazole against gastrointestinal nematodes of cattle, with emphasis on inhibited early fourth stage Ostertagiaostertagi larvae.Vet. Parasitol., 40:59-71. 